\title{
Medico-legal Conclusions Caused by Misevaluation of the Schmorl's Node, Which is Rarely Seen in Children (Case Report)
}

\author{
Çocuklarda Nadir Görülen Schmorl Nodülünün Yanlış Değerlendirilmesinin Yol \\ Açabileceği Hukuki Sonuçlar (Olgu Sunumu)
}

(D) Mahmut Aşırdizer MD. Prof. ${ }^{1}$, (1) Mehmet Arslan MD. Prof.2 , (1) Uğur Demir MD. ${ }^{3}$, (1) İrem Sarı Karabağ MD.4, (D) İsmail Oymak MD.5

\author{
${ }^{1}$ Bahçeşehir University Faculty of Medicine, Department of Forensic Medicine, İstanbul, Turkey \\ ${ }^{2}$ Van Yüzüncü Yıl University Faculty of Medicine, Department of Neurosurgery, Van, Turkey \\ ${ }^{3}$ Tokat State Hospital, Tokat, Turkey \\ ${ }^{4}$ Ondokuz Mayıs University Faculty of Medicine, Department of Pediatric Radiology, Samsun, Turkey \\ 5 Van Yüzüncü Yıl University Faculty of Medicine, Department of Forensic Medicine, Van, Turkey
}

\section{ABSTRACT}

Schmorl's node (SN) is disruption of the cartilaginous endplate and herniation of the nucleus pulposus into the vertebral body in the period after losing of nuclear material through the cartilage plate. This article is about a 12-year-old boy, who was injured in a traffic accident. His traumatic vertebral compression fracture was defined and a causality was established between this lesion and the traffic accident. As a result of evaluation with neurosurgery, radiology and pediatric radiology, it was concluded that this lesion was SN and was not associated with the traffic accident. The literature about the case presented in this article was reviewed, and the importance of establishment of causality while preparing a forensic report and the necessity of multidisciplinary approach in such cases were emphasized.

Keywords: Schmorl's Node, child, vertebral compression fracture, radiological imaging, causality

\section{$0 \ddot{z}$}

Schmorl nodülü (SN), kıkırdak uç plakanın bozulması ve kıkırdak plakası yoluyla nükleer madde kaybolduktan sonraki dönemde, nükleus pulposusun vertebra gövdesine herniasyonudur. Bir trafik kazasında yaralanan 12 yaşında bir erkek çocuğu hakkındaki bu makalede, travmatik vertebra kompresyon kırı̆ı tanımlanmış ve bu lezyon ile trafik kazası arasında bir nedensellik bağı tespit edilmişti. Beyin cerrahisi, Radyoloji ve Pediatrik Radyoloji ile yapılan değerlendirmeler sonucu bu lezyonun SN olduğu ve trafik kazası ile ilişkili olmadığı sonucuna varıldı. Bu makalede sunulan olgu ile ilgili literatür gözden geçirilerek adli rapor hazırlanırken nedenselliğin tesis edilmesinin önemi ve bu tür durumlarda multidisipliner yaklaşımın gerekliliği vurgulanmıştır.

Anahtar Kelimeler: Schmorl nodülü, çocuk, vertebral kompresyon kırı̆̆ı, radyolojik görüntüleme, nedensellik

Address for Correspondence/Yazıșma Adresi: Mahmut Așırdizer MD. Prof., Bahçeșehir University Faculty of Medicine, Department of Forensic Medicine, İstanbul, Turkey

E-mail: masirdizer@yahoo.com

ORCID ID: orcid.org/0000-0001-7596-5892
Received/Geliș tarihi: 18.07.2020 Accepted/Kabul tarihi: 25.09.2020 


\section{INTRODUCTION}

Schmorl's node (SN) that was firstly defined in 1858 by von Luschka and was named in 1927 by Christian Georg Schmorl and commonly seen in the lumbar spine and lower part of thoracic vertebral column was described as disruption of the cartilaginous end plate and herniation of the nucleus pulposus into the vertebral body in the period after losing of nuclear material through the cartilage plate (1-5).

The pathogenesis of SNs has been explained by four theories to be "embryological developmental defects", "degeneration due to aging", "pathological changes due to diseases involving the vertebral column" and "effects of acute and chronic traumas on vertebral column" (2). However, the etiology of SNs has not yet been fully elucidated $(3,4)$.

The prevalence of SN in adults reported as from $20 \%$ to $76 \%$ in different autopsy studies (6-9). Stäbler et al. (10) defined to be $38 \%$ incidence of SN in radiological examinations in adults (10). Sonne-Holm et al. (11) reported that $5 \%$ of males and $3 \%$ of females had SNs in the radiological examination performed on 4151 persons between the ages of 18-92 (11). The incidence of SNs in children was not defined however; few cases were reported in literature investigated by us (12-15).

It is extremely important to make accurate medical descriptions of traumatic lesions that constitute a source for legal forensic reports and are considered legal evidence. A defective or incomplete identification may make the legal solution difficult. Because, this inaccurate identification causes misinterpretations of the experts or issuing a wrong report which may change the direction of the judicial investigation lead to false convictions or acquittal decisions (16).

In this article, a SN case which is rarely seen in children and was mistakenly described as a "traumatic vertebral compression fracture" was submitted and the forensic medical problems that may be caused by this misidentification were discussed.

\section{CASE REPORT}

A 12-year-old boy was injured by impact of a car in a traffic accident. On his first admission to the state hospital, he complained of pain in his head, right shoulder, lumbar region and hip. Physical examination revealed hematoma under the scalp in frontal region and dermal abrasions of right arm and at back of the body. In the computed tomography (CT) examinations, right clavicle fracture, humeral supracondylar fracture, lumbar vertebra fracture and sacrum fracture were defined. There was no internal organ injury in the child. In the lumbar vertebrae magnetic resonance imaging (MRI), the height loss was thought to be associated with SN in anterior part of the upper plateau of the L5 vertebra, transformation of red marrow into yellow marrow around this area, slight reduction in the intensity of the L4-L5 intervertebral disc were seen. The patient was transferred to the orthopedic clinic after 36 hours of intensive care. The patient was discharged four days after the incident following the non-surgical treatment in this clinic. In the medical board report prepared by physical therapy clinic of the same hospital about two months after the incident, 25\% to $50 \%$ traumatic collapse fracture in the corpus of L5 vertebra was defined and $13 \%$ disability rate was reported.

In the CT report of the lumbar vertebra prepared approximately four months after the event, limbus vertebra in anterior segment of the L5 vertebra corpus, height loss in anterior section secondary to limbus vertebra, posterior arch fusion defect in posterior section of the S1 vertebra corpus were described.

According to the forensic report prepared by the forensic medicine specialist and the orthopedics and traumatology specialist about six months after the incident, there was no causality between the height loss in the $L 5$ vertebra corpus and car-accident and it was associated with a disease sequela which was defined as a $\mathrm{SN}$ in the radiology report.

In lumbar vertebra CT report prepared by the radiology department of a university hospital in 11th month following incident, slight height loss (compression fracture?) at upper end plate of the L5 vertebra were seen.

On the same day, the patient applied to the forensic outpatient clinic for a disability report. Physical examination revealed no functional disturbance, and healing findings in right clavicle, supracondylar humeral and sacrum fractures were seen in the radiological examination. The patient's neurological examination was normal and there was no neurovascular deficit. CT and MRI of the lumbar vertebra of the patient, which were both recently obtained and obtained at the time of the event, were examined together by forensic medicine, neurosurgery, radiology and pediatric radiology specialists (Figure 1, 2). In the radiological examinations made on the date of the incident, although mild collapse was seen in the anterior-upper part of the $\mathrm{L} 5$ vertebra, the absence of hematoma and/or edema around the bony lesion, and the presence of blunting and sclerosis at the edges of this lesion excluded a new fracture that

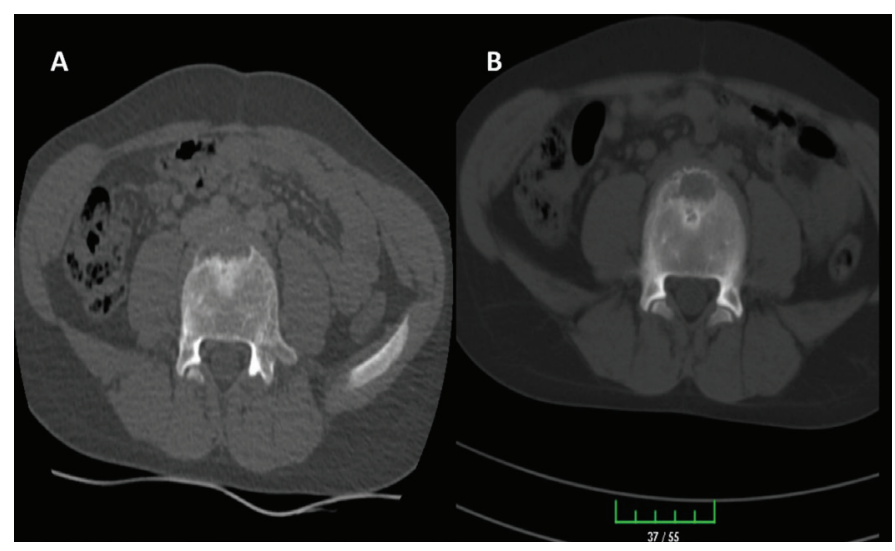

Figure 1. CT images of SN taken in event date (A) and 11th month of event (B) 
occurred at the time of the event. Moreover, this lesion preserved almost the same appearance in radiological examinations 11 months after the event. According to these findings obtained in this multi-disciplinary radiological examination, we decided that lumbar vertebra lesion was associated with SN and there was not a causality between lumbar vertebra lesion and caraccident.

\section{DISCUSSION}

Fractures of the spine in children and adolescents are rare due to stiffness of vertebral end plate and vascular supply of annulus fibrosus up to age of 20 (17-19). In the pediatric population, vertebral fractures represent $0.2-3 \%$ of all fractures and structural lesions represent $0.6-3 \%$ of all spinal damages $(17,19)$. The etiology of vertebral compression fractures is generally associated with traumas, osteoporosis and neoplastic infiltrates in elderly and some diseases $(20,21)$. In children, primary cause of vertebral compression fractures were defined as traumas such as motor vehicle accidents, falls and sports injuries. Also, $5^{\text {th }}$ lumbar vertebra was defined as the least affected spinal region in these traumas $(19,22)$.

In MR imaging, soft tissue and/or marrow edema is accepted as one of the evidences of traumatic vertebral fracture occurred in recent $(23,24)$. While the presence of hematoma can be evaluated in favor of acute traumatic fractures, in the absence of hematoma, the distinction of traumatic or nontraumatic is difficult (21).

SNs in radiographic and tomographic images is defined as "usually typical lesions with a small, focal, rounded form, and radiolucency in the subchondral bone of the vertebral body, broad-based at the vertebral plateau and with varying degrees of adjacent reactive sclerosis" (1).

In the present case, depiction of the slight collapse in the anterosuperior part of the L5 vertebra in the radiological examinations taken in event date, the absence of hematoma and/or edema around bone lesion, and the presence of blunting and sclerosis at the edges of this area were exclusion

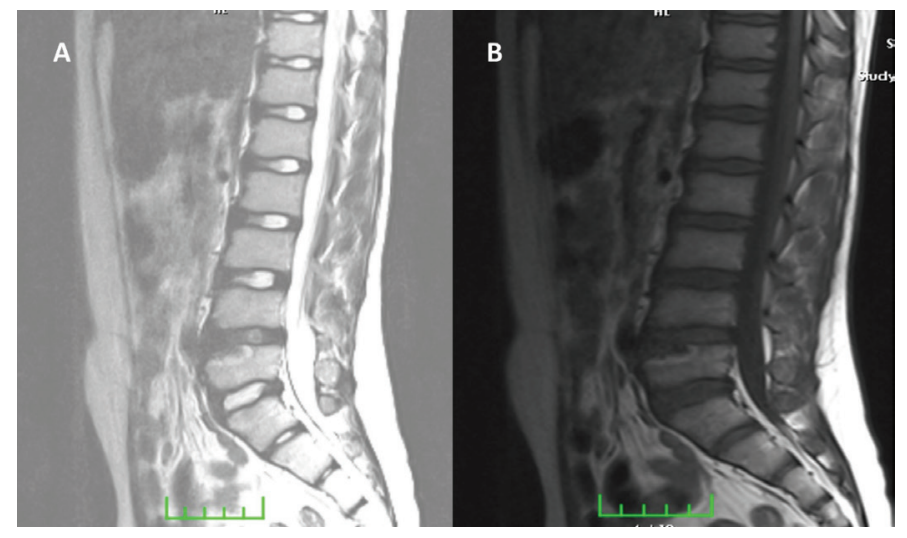

Figure 2. Radiological images of SN were obtained by $C T(A)$ and MRI (B) in 11th month of event criteria for a recent traumatic lesion occurred on the incident date.

Mistakenly description of a SN case as a "traumatic vertebral compression fracture" and establishing a causality between this lesion and the traffic accident to which the person was exposed, can lead to some important forensic medical problems. During the assessment of injuries according to the Turkish Penal Code, establishing a causality between fracture of the vertebral bone and car accident will be an aggravating factor on punishment of driver. Likewise, this error will also affect the degree of disability of the victim and cause the defendant to pay more compensation.

For this reason, clinicians and radiologists should be more careful in the evaluation of forensic cases and should not refrain from consulting other specialists including forensic medicine experts in cases where they cannot make decisions. As seen in the presented case, although radiological diagnoses that are terminated with a question mark in forensic cases are preferred by radiologists to protect themselves, they should be minimized as they constitute important handicaps in the decision-making process in preparing forensic reports.

\section{CONCLUSION}

In this article, a SN case was reported which is rarely seen in children. It was described as "traumatic collapse fracture" and "compression fracture?" in two radiology reports. Before our multidisciplinary review, clinicians made an erroneous conclusion based on these radiology reports and found a causality between this lesion and a traffic accident and defined the disability rate as $13 \%$. In acute spinal traumas, MRI has a very important role in determining soft tissue damage around bone lesions seen on $\mathrm{CT}$, and the presence or absence of these damages plays an important role in the establishment of the causality in forensic cases. As in our case, forensic reports to be issued without establishing a causality may result in erroneous punishment or compensation. Consequently, this paper emphasizes the importance of multidisciplinary approach for refraining from misevaluation of a medico-legal case.

\section{Ethics}

\section{Ethical Declaration}

Informed consent was obtained from the participant and Helsinki Declaration rules were followed to conduct this study.

Peer-review: Internally peer-reviewed.

\section{Authorship Contributions}

Surgical and Medical Practices: M.A., I.O., Concept: M.A., M.AR., I.S.K., Design: M.A., M.AR., Data Collection or Processing: U.D., Analysis or Interpretation: M.AR., I.S.K., Literature Search: U.D., I.O., Writing: M.A., I.O. 
Conflict of Interest: No conflict of interest was declared by the authors.

Financial Disclosure: The authors declared that this study received no financial support.

\section{REFERENCES}

1. Nogueira-Barbosa MH, Crema MD, da Silva Herrero CFP, Pasqualini W, Aparecido Defino HL. The several faces of schmorl's node: pictorial essay. Coluna. 2015;14(4):320-323. https://doi.org/10.1590/S1808185120151404151248

2. Fahey V, Opeskin K, Silberstein M, Anderson R, Briggs C. The pathogenesis of schmorl's nodes in relation to acute trauma. an autopsy study. Spine. 1998;23(21):2272-2275. https://doi.org/10.1097/00007632-19981101000004

3. Hasegawa K, Ogose A, Morita T, Hirata Y. Painful schmorl's node treated by lumbar interbody fusion. Spinal Cord. 2004;42(2):124-128. https://doi. org/10.1038/sj.sc.3101506

4. Kyere KA, Than KD, Wang AC, Rahman SU, Valdivia-Valdivia JM, La Marca F, et al. Schmorl's Nodes. Eur Spine J. 2012;21(11):2115-2121. https://doi. org/10.1007/s00586-012-2325-9.

5. Takahashi K, Takata K. A large painful schmorl's node: a case report. J Spinal Disord. 1994;7(1):77-81. https://doi.org/10.1097/00002517-19940701000011

6. Batts M, Michagan AA. Rupture of the nucleus pulposus. J Bone Jt Surg. 1939;21(1):121-126.

7. Resnick D, Niwayama G. Intravertebral disk herniations: cartilaginous (schmorl's) nodes. Radiology. 1978;126(1):57-65. https://doi. org/10.1148/126.1.57

8. Pfirrmann CW, Resnick D. Schmorl nodes of the thoracic and lumbar spine: radiographic-pathologic study of prevalence, characterization, and correlation with degenerative changes of 1,650 spinal levels in 100 cadavers. Radiology. 2001;219(2):368-374. https://doi.org/10.1148/ radiology.219.2.r01ma21368

9. Hilton RC, Ball J, Benn RT. Vertebral end-plate lesions (schmorl's nodes) in the dorsolumbar spine. Ann Rheum Dis. 1976;35(2):127-132. https://doi. org/10.1136/ard.35.2.127

10. Stäbler A, Bellan M, Weiss M, Gärtner C, Brossmann J, Reiser MF. MR imaging of enhancing intraosseous disk herniation (schmorl's nodes). AJR Am J Roentgenol. 1997;168(4):933-938. https://doi.org/10.2214/ajr.168.4.9124143

11. Sonne-Holm S, Jacobsen S, Rovsing H, Monrad H. The epidemiology of schmorl's nodes and their correlation to radiographic degeneration in 4,151 subjects. Eur Spine J. 2013;22(8):1907-1912. https://doi.org/10.1007/s00586013-2735-3

12. Sandelich SM, Adirim TA. An unusual cause of back pain in a 10-year-old girl. Pediatr Emerg Care. 2017;33(5):352-355. https://doi.org/10.1097/ PEC.0000000000000808

13. Fukuta S, Miyamoto K, Iwata A, Hosoe $\mathrm{H}$, Iwata $\mathrm{H}$, Shirahashi $\mathrm{K}$, et al. Unusual back pain caused by intervertebral disc degeneration associated with schmorl node at th11/12 in a young athlete, successfully treated by anterior interbody fusion: a case report. Spine. 2009;34(5):E195-E198. https://doi.org/10.1097/BRS.0b013e318198c60cXXX

14. Walters G, Coumas JM, Akins CM, Ragland RL. Magnetic resonance imaging of acute symptomatic schmorl's node formation. Pediatr Emerg Care. 1991;7(5):294-296. https://doi.org/10.1097/00006565-199110000-00009

15. Swischuk LE, John SD, Allbery S. Disk degenerative disease in childhood: scheuermann's disease, schmorl's nodes, and the limbus vertebra: MRI findings in 12 patients. Pediatr Radiol. 1998;28(5):334-338. https://doi. org/10.1007/s002470050368

16. Zeyfeoğlu Y, Uluçay T, Yavuz MS, Așirdizer M. Incorrect identification in forensic medicine (wrong conclusion): a case report. Ulus Travma Acil Cerrahi Derg. 2010;16(2):185-188.

17. Reynolds R. Pediatric spinal injury. Curr Opin Pediatr. 2000;12(1):67-71. https://doi.org/10.1097/00008480-200002000-00013.

18. Rudert M, Tillmann B. Lymph and blood supply of the human intervertebral disc. cadaver study of correlations to discitis. Acta Orthop Scand. 1993;64(1):37-40. https://doi.org/10.3109/17453679308994524

19. Saul D, Dresing K. Epidemiology of vertebral fractures in pediatric and adolescent patients. Pediatr Rep. 2018;10(1):7232. https://doi.org/10.4081/ pr.2018.7232

20. Mauch JT, Carr CM, Cloft H, Diehn FE. Review of the imaging features of benign osteoporotic and malignant vertebral compression fractures. AJNR Am J Neuroradiol. 2018;39(9):1584-1592. https://doi.org/10.3174/ajnr.A5528

21. Panda A, Das CJ, Baruah U. Imaging of vertebral fractures. Indian J Endocrinol Metab. 2014;18(3):295-303. https://doi.org/10.4103/2230-8210.131140

22. Joffe A, Bartley CE, Bastrom TP, Newton PO, Yaszay B. Thoracic and lumbar compression fractures in patients presenting to a pediatric institution. WSCJ. 2015;6(3):115-121.

23. Guglielmi G, Muscarella S, Leone A, Peh WC. Imaging of metabolic bone diseases. Radiol Clin North Am. 2008;46(4):735-754. https://doi org/10.1016/j.rcl.2008.04.010 https://doi.org/10.1016/j.rcl.2008.04.010

24. Kumar Y, Hayashi D. Role of magnetic resonance imaging in acute spinal trauma: a pictorial review. BMC Musculoskelet Disord. 2016;17:310. https:// doi.org/10.1186/s12891-016-1169-6 